

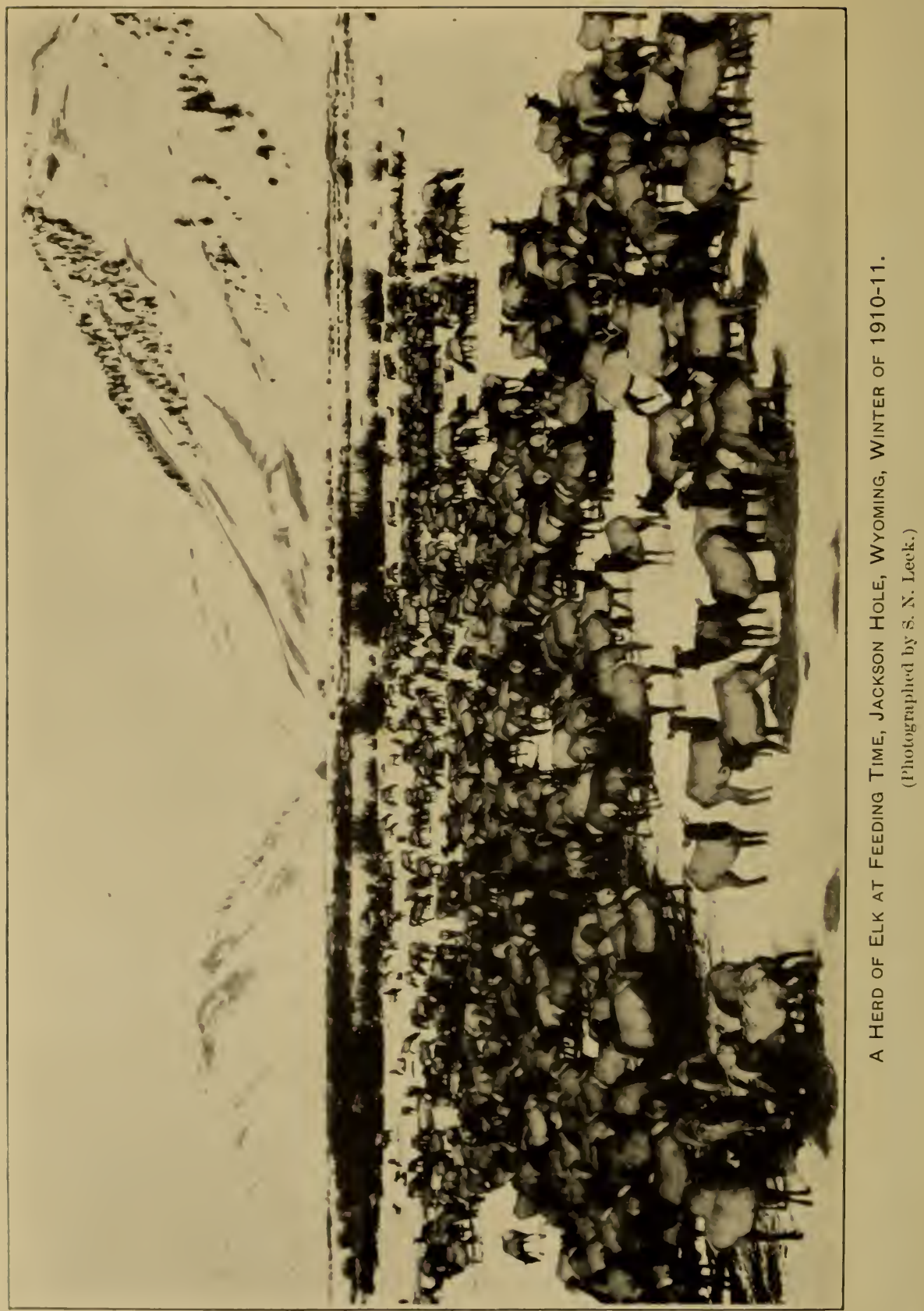


Issued December 21, 1911.

U. S. DEPARTMENT OF AGRICULTURE BIOLOGICAL SURVEY-BULLETIN No. 40

HENRY W. HENSHAW, Chief

\section{REPORT ON CONDITION OF ELK IN JACKSON HOLE, WYOMING, IN 1911}

BY

EDWARD A. PREBLE

Assistant, Biological Survey

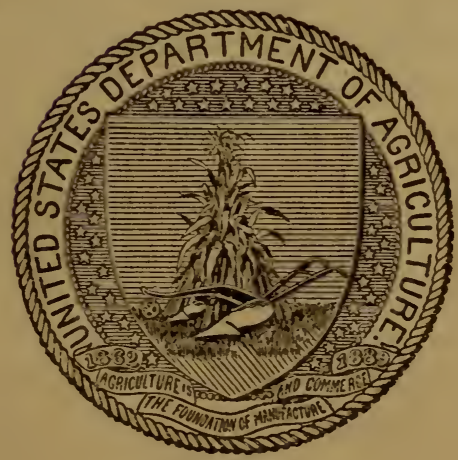

WASHINGTON

GOVERNMENT PRINTING OFFICE 1911 



\section{LETTER OF TRANSMITTAL.}

\section{U. S. Department of Agriculture, Bureau of Biological Strvey, Washington, D. C., November 1, 1911.}

SIR: I have the nonor to transmit herewith for publication as Bulletin No. 40, a Report on the Condition of Elk in Jackson Hole, Wyoming, in 1911, by Edward A. Preble, assistant in the Biological Survey. At the last session of the sixty-first Congress an item was incorporated in the appropriation for the Biological Survey "for the feeding, protecting, and remoral of elk in the country known as Jackson's Hole and ricinity, in the State of Wyoming." Steps were immediately taken to obtain the information necessary to enable the Biological Survey to undertake intelligently and effectively the solution of the elk problem in Wyoming. Mr. Preble was directed to proceed to Jackson Hole, and Mr. D. C. Nowlin, formerly game warden of the State, was appointed as his assistant. They were instructed: (1) To make a thorough examination of existing conditions, to ascertain approximately the number of elk which perished by starration, and to collect all arailable data respecting the life history and local distribution of the animals; (2) to cooperate with the State in feeding the elk and to arrange for obtaining a supply of feed for the winter of 1911-12; (3) to investigate the feasibility of transferring a few animals to other parts of the State or to game preserves in other States where nucleus herds might be established under Federal or State auspices. Upon arriral in Jackson Hole Messrs. Preble and Nowlin found that the State had already purchased and was feeding all the hay arailable and nothing further in this direction could be done except to make arrangements for the following winter. On account of the lateness of the season and the impassability of the roads it was practicable to make only one experimental shipment of elk, and 12 animals were successfully transported across Teton Pass. Seven of these were shipped to the National Bison Range, in Montana, and 5 to the Wichita National Game Refuge, in Oklahoma. All of them arrived in good condition and are doing well.

The Biological Surrey has undertaken not merely temporary relief during one or two severe winters, but an investigation, in cooperation with the State of $T$ yoming, of the broader problem of the maintenance of the elk herd of Jackson Hole as one of the important resources of the State and as a permanent source of income. Such an 
investigation includes collection of all available data on the natural history of the elk; a review of the efforts which have been made by the State to protect and perpetuate the species; the losses by wolves, poaching, and starvation; experiments in feeding during severe weather; provision for summer range in the State game preserve; and recommendations for winter refuges where an adequate supply of forage may be obtained. The present publication is a preliminary report and deals mainly with the information collected regarding the condition of the elk during the past winter. It will probably be followed shortly by a summary of the work accomplished by the State, and later by reports on feeding and refuges and other problems concerning which data are not yet ready for publication.

Respectfully,

Hon. James Wilsox,

Henry W. Henshaw, Chief, Biological Survey.

Secretary of Agriculture. 


\section{CONTENTS.}

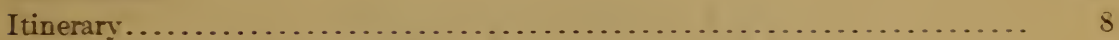

General description of the region................................ 9

Value of elk to the region..................................... 11

Number of elk in Jackson Hole region........................ 12

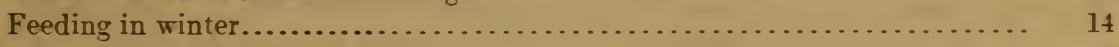

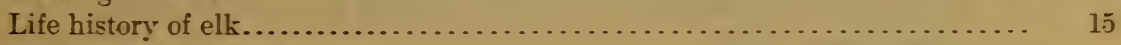

Distribution in summer..................................... 15

Morements in autumn...................................... 15

Depredations in winter................................... 16

Habits in winter..........................................

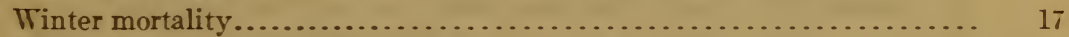

Habits in spring and early summer............................. 15

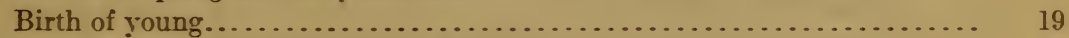

Habits in late summer and in autumn..................... 20

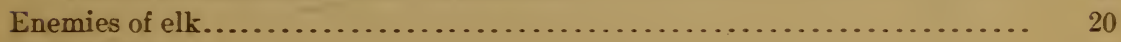

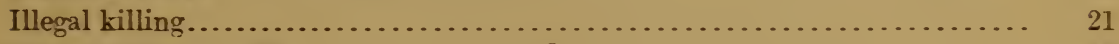

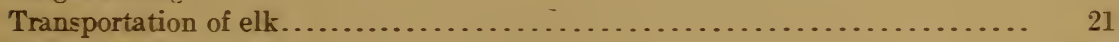

Winter refuge for elk.......................................... 22 


\section{ILLUSTRATIONS.}

Plate I. A herd of elk in Jackson Hole, Wyoming, in winter of 1910-11. Frontispiece.

II. Map of part of northwestern Wyoming, showing summer and winter

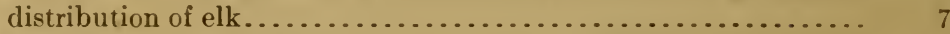

III. Map of Jackson Hole region........................... 10

IV. Fig. 1.-Teton Range, bordering Jackson Hole on the west. Fig. 2.Marsh bordering Little Ğros Ventre or Flat Creek above Jackson. . 10

V. Feeding elk in South Park near Jackson in late winter, 1910-11.... 14

VI. Fig. 1.-Elk calves in South Park below Jackson. Fig. 2.-Elk calves around haystack............................ 20

VII. Elk in the foothills of Jackson Hole in early winter........... 20 


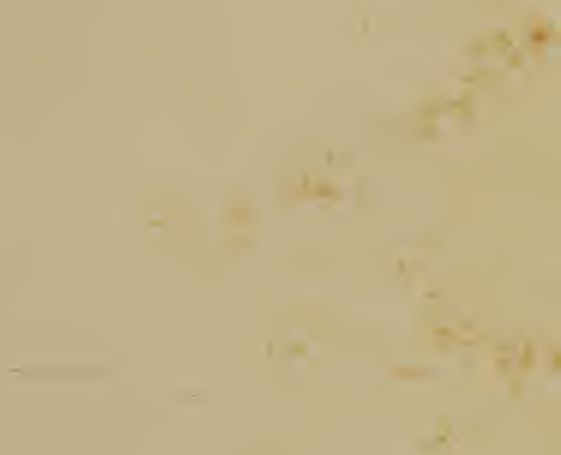




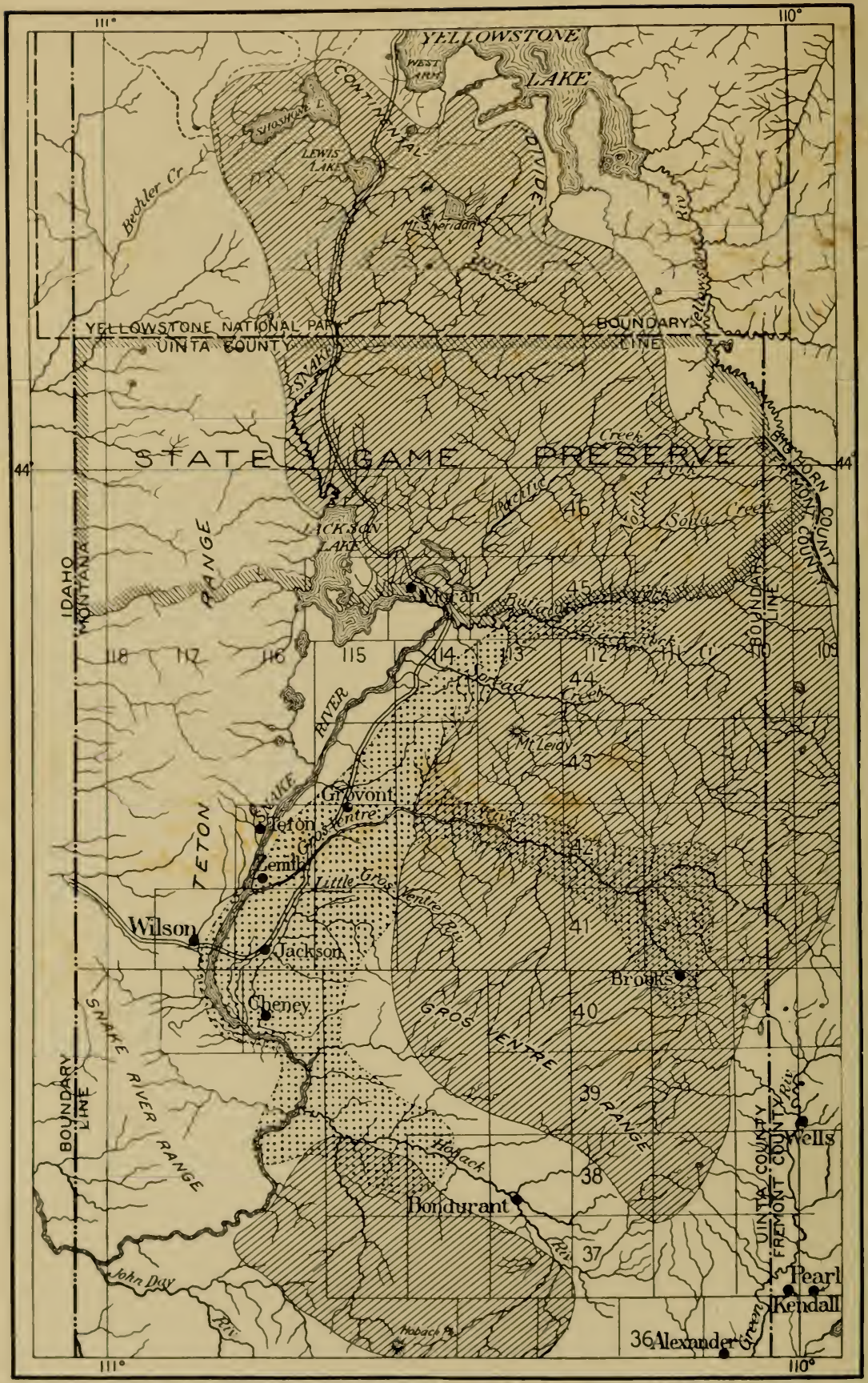

PART OF NORTHWESTERN WYOMING, SHOWING APPROXIMATE RANGE OF ELK WHICH WINTER IN JACKSON HOLE.

WISISISISlli, summer range. $\quad \because \because \because \because \because$ winter range. 


\section{REPORT ON CONDITION OF ELK IN JACKSON HOLE, WYOMING, IN 1911.}

\section{INTRODUCTION.}

That part of the valley of Snake River in northwestern Wyoming usually called Jackson Hole has long been the principal winter home of large numbers of elk, or wapiti (Cervus canadensis). These animals, which spend the summer in the southern part of Yellowstone National Park and in the mountains south of it, are forced in winter to seek lower levels, where a lighter snowfall and a milder climate insure more favorable forage conditions. Their primitive winter range has gradually been reduced, until this basin has become their principal stronghold. Here, until recent years, the herds have fared well, except in an occasional abnormal winter; but with increased settlement in this valley has come depletion of the range by grazing. The elk have come down in their old or even in augmented numbers only to find their former haunts shorn of forage by cattle, and when unusual winter conditions have conspired with a lessened food supply, great suffering and loss of life have ensued. Such was the case during the winters of 1908-9 and 1909-10, and during that of 1910-11, when an almost unprecedented fall of snow following a dry summer covered to a depth of several feet the remnant of a scanty crop of grass, conditions became acute. The elk sought the valley in about their normal numbers, but a little earlier than usual, and before the winter was half over had suffered great loss. The State legislature was appealed to and promptly appropriated money to buy food for the starving creatures. Moreover, the State, realizing its inability to cope with the situation unaided, presented the following memorial to Congress:

House Joint Memorial No. 1.

A joint resolution relating to the preservation of big game in the State of Wyoming, and memorializing the Congress of the United States to make an adequate appropriation to aid the State of Wroming in providing winter food for and otherwise protecting the big game which range in the National Park and in the Jackson Hole region of this State, alternately.

$B e$ it resolved by the house of representatives (the senate concurring):

Whereas the principal remnant of the big game of the United States, comprised of moose, elk, and deer, range alternately during the winters in the National Park 
and game reserve and the Jackson Hole section of the State of Wyoming, south of the National Park; and

Whereas during the winters they suffer greatly and perish from famine in large numbers, which could be in a great measure prevented by adequate and systematic provision for feeding and protecting them during storms and blizzards; and

Whereas the State of Wyoming has been and is making appropriations of large sums of money and using every available means within its power to preserve said big game; and

Whereas the sufficient and thoroughly adequate protection of said big game is too expensive and burdensome to be borne alone by the State of Wyoming: Therefore be it

Resolved by the Legislature of the State of Wyoming, That the Government of the United States be, and is hereby, requested to cooperate with the State of Wyoming in feeding, protecting, and otherwise preserving the big game which winters in great numbers within the confines of the State of Wyoming; and the Congress of the United States is hereby memorialized and requested to make an adequate appropriation of money, to be used in aiding and cooperating with the State of Wyoming in the laudable and desirable effort to feed, protect, and preserve from extinction the principal remnant of the big game of the United States, which range during the winters principally within the territory of the State of Wyoming; be it further

Resolved, That engrossed copies of this memorial and request be sent to the President of the United States, to the President of the United States Senate, to the Speaker of the United States House of Representatives, and to the Secretary of the Interior, asking their aid in bringing the object of this memorial and request before Congress and in securing from same an adequate appropriation of public moneys for the noble, humane, and national purpose herein set forth; and be it further

Resolved, That engrossed copies of this memorial and request be sent to the Senators from Wyoming in the Congress of the United States, viz., Hons. Clarence D. Clark and Francis E. Warren, and our Representative in said Congress, Hon. Frank W. Mondell, asking them to use their best efforts to secure favorable action upon the request embodied herein.

Approved February 17, 1911.

In accordance with this memorial the act approved March 4, 1911, making appropriations for the Department of Agriculture, included an item of $\$ 20,000$ immediately available for feeding, protecting, and removing elk in Jackson Hole and vicinity. The administration of this fund was intrusted to the Biological Survey, and to the writer was assigned the task of making the preliminary investigation.

\section{ITINERARY.}

I. left Washington on March 7, 1911, and reached Cheyenne, Wyo., March 9. Here I was joined by Mr. D. C. Nowlin, formerly State game warden, who was to be associated with me in the work. Pursuant to my instructions, conferences with Gov. Joseph M. Carey were held on March 10 and 11. The governor, as chairman of the newly established game commission, expressed himself as pleased to see steps taken toward Federal cooperation in the protection of the elk, and furnished me letters of introduction and a permit to capture a number of animals for removal to parks in other States. On March $12 \mathrm{Mr}$. D. F. Hudson, the present State game warden, joined us, and 
the next day Mr. Hudson, Mr. Nowlin, and I left Cheyenne for Jackson Hole, via Pocatello and St. Anthony, Idaho. To reach the scene of our work, a two days' stage trip after leaving the railroad was necessary. We left St. Anthony on March 15 and passed the night at Victor, Idaho, close to the western base of the lofty and picturesque Teton Range. Next day we crossed this range, over from 10 to 40 feet of snow, via the Teton Pass, at 8,429 feet altitude, and descending the eastern slope of the range crossed Snake River and reached the town of Jackson. This point, in the southern part of Jackson Hole, was our headquarters for nearly three months. From here we made trips by stage and other conveyances and on foot to various parts of the valley of Snake River from the head of Jackson Lake south nearly to Hoback River and visited also the valleys of Buffalo and Gros Ventre Rivers. We left the valley in early June to take up other work, but Mr. Nowlin returned about August 1 and continued the investigations.

During the progress of the work I was greatly assisted by Mr. Nowlin. His intimate personal acquaintance with the people of the region and with the various phases of the problem made him peculiarly valuable. To the residents of the region, also, I am greatly indebted for courtesies extended.

\section{GENERAL DESCRIPTION OF THE REGION.}

Jackson Hole is the name commonly applied to that part of the Snake River Valley between Jackson Lake and the mouth of Hoback or Fall River. (See map, PI. III.) It is a basin about 40 miles in length from north to south and averaging about 15 miles in width and extends in a north-northeast and south-southwest direction. It has an altitude of about 6,700 feet at its north end and falls to about 6,000 feet at its southern extremity. Snake River, after issuing from Jackson Lake, traverses the valley in a direction slightly nearer southwesterly than the general trend of the basin, entering it at its northeastern extremity and crossing to its western border in the course of a few miles. This river has a rather uniformly rapid current and is moderately direct in its course, but in places divides into numerous channels inclosing large islands. From the east it receives successively Pacific Creek (whose twin, Atlantic Creek, heading in the same meadow, is tributary to the Missouri), Buffalo River or Buffalo Fork, Gros Ventre River, and Little Gros Ventre or Flat Creek. Parts of Snake River and its larger tributaries are bordered by groves of narrow-leaf cottonwoods (Populus angustifolia), interspersed with a few spruces, with an undergrowth of dogwood, alder, and other shrubs. Along some of the tributaries of Snake River are natural marshy mearlows which support a rank growth of marsh grasses, with thickets of willows on their borders and along the streams, and a $15973^{\circ}-$ Bull. $40-11-2$ 
variety of marsh-loving shrubs and other plants on their drier parts. One of the more extensive of these meadows lies along little Gros Ventre Creek above the town of Jackson, and will be referred to in more detail later.

By far the greater part of the area embraced in the basin called Jackson Hole is covered by a fairly rank growth of sagebrush (Artemisia tridentata and $A$. cana). Large areas of this land have been cleared and under irrigation produce fine crops of alfalfa and timothy and fair yields of oats, barley, and wheat. The altitude of the valley and the proximity of large areas of high mountains cause frost to be common through May and in exceptional seasons in August. The shortness of the growing season prevents the successful raising of any but forage crops besides the hardier grains and roots, except in a few favored localities.

The winters are long and severe and the snowfall heavy, though the amount in any particular section varies greatly from year to year. Thus, while the depth of snow is usually greater in the upper Gros Ventre Valley than about Jackson, the contrary was the case during the winter of 1910-11. The amount of snow which fell in the Valley of Spread Creek was also much less than on Antelope Flat, only a few miles distant, or about Jackson, though all three places are near the same altitude. These local fluctuations seem to be due to the proximity of the lofty Teton Range, which influences to a remarkable degree the direction and intensity of local storms. In early January, 1911, about 4 feet of snow fell within 48 hours in some parts of the valley. On the mountains the amount of snow is, of course, much greater and the winter of longer duration than in the valley. On the Teton Pass ( 8,429 feet), practically the only means of access to the valley, snowstorms are frequent until midsummer, and even in the lower part of the valley it is not unusual for snow to fall in late May and in September.

In the spring of 1911 the winter's snow was practically gone in the main part of the valley on $\Lambda$ pril 20 , but the mountains and foothills above 7,000 feet were as white as in midwinter.

Bordering the valley on the west is the Teton Range, a succession of rocky crags with altitudes varying from about 10,000 to nearly 14,000 feet. (See Pl. IV, fig. 1.) These rise abruptly from the comparatively low and level valley (6,000 to 6,700 feet), affording a panorama whose equal in rugged grandeur is rarely seen. To the east the valley is bordered by foothills of the Gros Ventre Range, some of whose peaks reach an altitude of about 11,000 feet. These mountains are treeless above 10,000 feet. Below this the mountain slopes are usually well wooded, the commoner trees being Engelmann spruce (Picea engelmanni), Douglas spruce (Pseudotsuga taxifolia), and aspen poplar (Populus tremuloides). Within the confines of the valley arise several so-called buttes, which rise about 1,000 feet above the general 


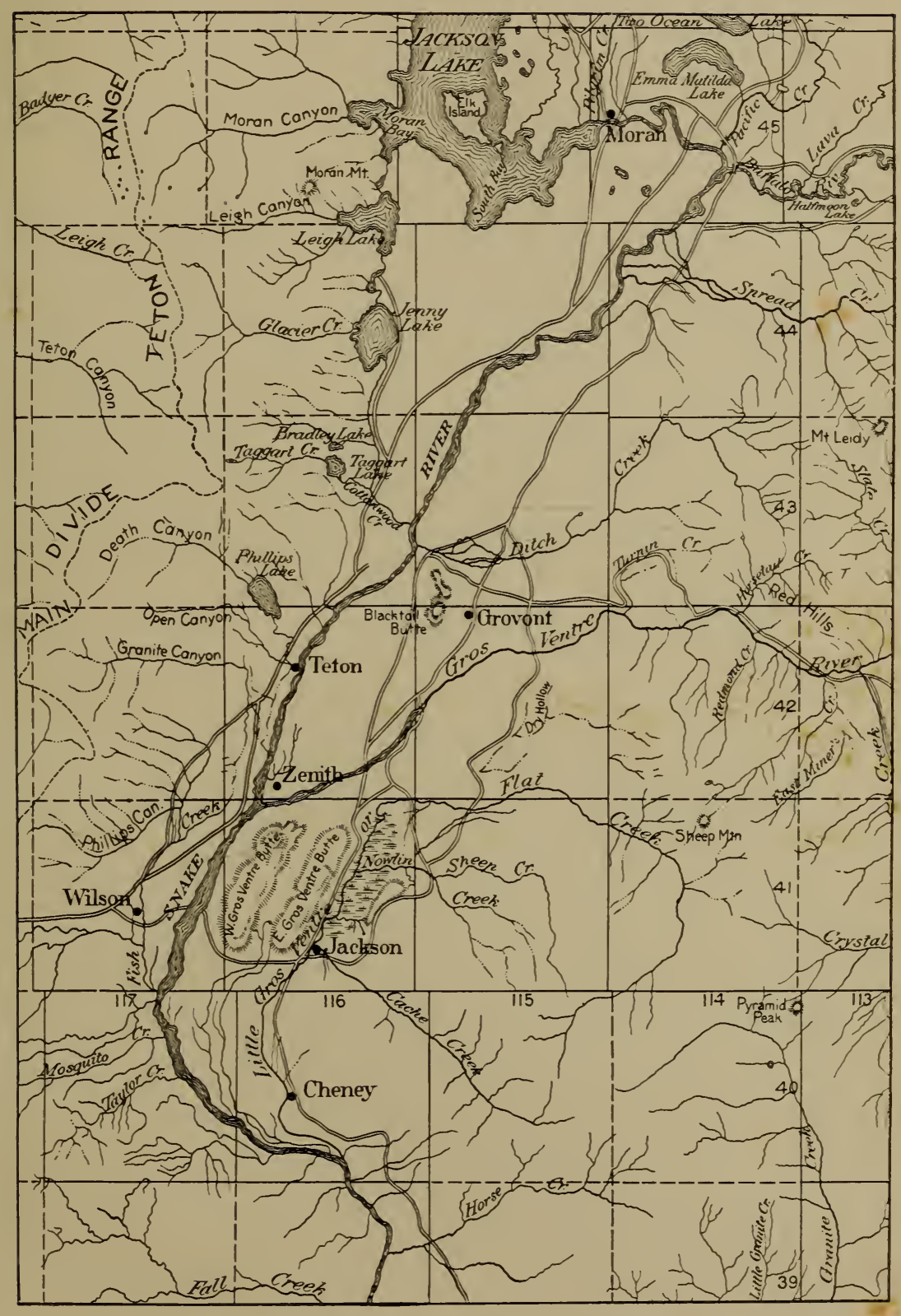

JACKSON HOLE AND VICINITY, WYOMING. 


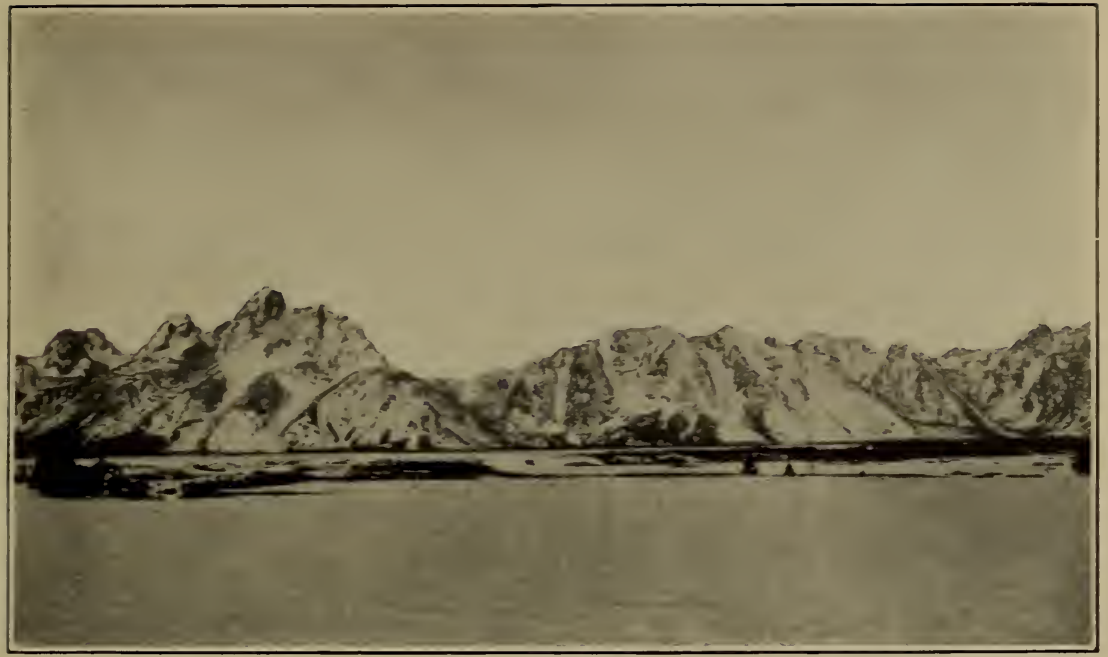

Fig. 1.-Teton Range, Bordering Jackson Hole on West. View from near GROVONT, MARCH 24, 1911.

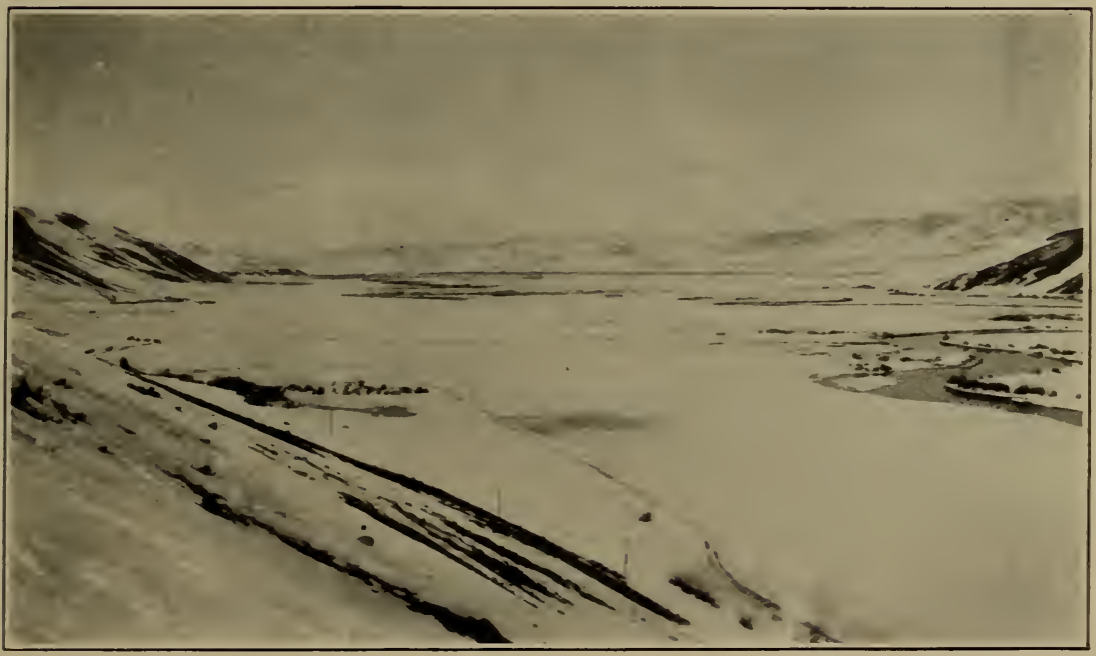

Fig. 2.-MARSh Bordering LitTle Gros Ventre or Flat Creek, above JaCkSON. VIEW NORTHEASTWARD FROM BASE OF EAST GROS VENTRE BUTTE, NEAR JACKSON, MARCH 21, 1911. 

level. These are mostly devoid of trees, but support a few groves of aspen poplar and an occasional juniper (Juniperus scopulorum), nut pine (Pinus flexilis), or Douglas spruce. These hills, especially during moist seasons, produce a growth of grasses and other herbaceous plants which are excellent for forage and, as their steep slopes are early bared of snow by the action of sun and wind, they furnish fine feeding grounds for both stock and game.

In this fertile valley, with its luxuriant growth of forage and comparatively mild climate, most of the elk which summer in the adjacent mountains and in the great area of high country extending northward into the Yellowstone National Park have lately spent the winters.

In former years large numbers, probably the great majority of those which summered in the high ranges of northwestern Wyoming, wintered on the Red Desert and other parts of the comparatively low country lying to the southward. Occupation of these tracts by sheep, with its attendant persecution and gradual depletion of the range, has forced the elk to confine their southward movements within ever-narrowing limits. Within the past few years the further march of settlement into the higher valleys, with the attendant utilization of the range for cattle grazing, has caused a serious diminution in the natural food supply available each winter for the elk.

Thus, although elk probably became more numerous in Jackson Hole after settlement began, it is painfully evident that during the past few years the encroachments of civilization and coincident unfavorable winter conditions have resulted in serious inroads on their numbers.

\section{VALUE OF ELK TO THE REGION.}

Some of the most intelligent residents of Jackson Hole have estimated that the value of the elk to the region is equal to the revenue derived from stock raising, which is the principal industry. Others, while considering this estimate excessive, admit that the value of the animals is very great, and that without them the region under present conditions would not support nearly so large a population as it now does. Whatever the opinion of individuals on this point, it is evident that elk have played a very important part in the development of the region. Probably a majority of the more successful residents owe their start to the presence of these animals. Many trappers and hunters who were first attracted to this part of the State by the abundance of game, and later by the opportunities which it offered for acting as guides to visiting sportsmen, have now extensive stock interests and have abandoned their former pursuits, while others still guide hunting parties.

The amount of money which the elk are instrumental in bringing into the country is very large. During the hunting season of 1910 , 
24 nonresident hunting licenses were granted in the four precincts of Jackson Hole, and in addition many parties who obtained licenses at other points-notably Cody, Lander, Dubois, Rock Springs, and Pinedale - hunted in tho Jackson IIole region. Hunters are obliged to hire suides, packers, cooks, and pack animals, and to provision the party. A conservative estimate places the average daily expense of a person hunting in this region at $\$ 14$. Thus, a trip of 30 days would cost each nomresident $\$ 420$. Practically all this is spent in the vicinity of the hunting grounds.

The food value of the animals killed by residents is also very large. During the season of 1910, 413 resident licenses, each good for the capture of two elk, were granted in Jackson Hole. It is fair to assume that $\$ 00$ elk, with an average value of $\$ 20$, not counting the value of hides, horns, and scalps, were taken under these licenses.

\section{NUMBER OF ELK IN JACKSON HOLE REGION.}

Any statement regarding the number of elk in the Jackson Hole region can be only approximate. This is evident since, out of the large number of estimates obtained from residents, the smallest and largest given by persons whose opportunities for intelligent judgment were about equal varied as one to four. The migratory habits of the animals and the difficulty of traveling during the season when they are most easily observed makes it difficult to judge their numbers. Careful consideration of all the data obtained leads me to estimate at from 20,000 to 25,000 the number which habitually range in the region drained by Snake River south and west of the Continental Divide in the southern part of the Yellowstone National Park, most of which spend the winter in the Jackson Hole region as above defined. Recent investigations have established the fact that a line approximately represented by the Continental Divide in the southern part of Yellowstone National Park separates the northward and southward migrating bands of elk. A conservative estimate of the number of Jackson Hole elk which summer north of Buffalo Fork, the southern boundary of the game preserve, is 12,000 , and of this number not more than 4,000 (or 20 per cent of the total number wintering in Jackson Hole) cross the boundary of Yellowstone Park to spend the summer. Owing, moreover, to the fact that snow remains deep on these high mountinins until very late, it is midsummer before this part of the park is suitable for occupancy. By mid-September snow has again begun to fall, and the elk start to move southward from the Divide and soon regain the game preserve, where the rest of the 12,000 have spent the summer.

The remaining 8,000 which complete the total of 20,000 , a conservative estimate of the number inhabiting the Jackson Hole region, spend the summer principally between Buflialo Fork and Gros Ventre 
River, and in the Gros Ventre Range to the southward between the Snake and Green River Valleys. A few hundred animals from the more easterly of these bands probably winter in the Green River Valley, but most of them seek Jackson Hole at that season.

Most of the residents consider that the elk have increased in numbers within the last 10 years, but nearly all agree that there has been a decided decrease within the last 3 jears. This is owing, of course, to the large number which died during these winters because of abnormal conditions.

Assuming that the elk number 20,000 and that the number of each sex is approximately the same, the herd just before calving time following a normal winter will be dirided approximately as follows:

5,425 cows 4 years old and over.

1,200 cows 3 years old.

1,500 cows 2 years old.

1,875 female calves.

10,000 females in all.

10,000 males in all, of approximately the same relative ages.

20,000

It is elsewhere estimated that from 2,000 to 2,500 elk starred to death in the Jackson Hole region in the winter of 1910-11, and it must be borne in mind that this disastrous season was preceded by two others notable for heary loss. It is plain that the animals can not maintain their numbers under such drains. But so high is the birth rate that elk will hold their own under a considerable winter loss.

The estimate already given is that a band of 20,000 elk will include about 6,625 cows 3 years old and over, of which about 75 per cent, or 4,968, will drop calves each year. If, then, the elk are not to fall below their present numbers, the total deaths from all causes must not exceed 4,968 per year; or, in other words, the total deaths each jear may rise to 4,968 and still the elk will hold their own.

The total death roll is the result of four causes: (1) Natural causes, including accidents; (2) starration; (3) wolves and other predatory animals; (4) hunting. It is evident that anything done to decrease losses from the first three causes will increase the number of elk that can be shot each year without diminishing the herd as a whole. But just in proportion as starvation or wolves claim a greater number of victims must the number shot be curtailed, or else the total of the elk will be diminished.

At present, probably about 2,000 elk a year are killed by hunters and about $1,000 \mathrm{by}$ wolves. If these figures are approximately correct, and if it is also true, as claimed, that under normal winter conditions the elk hold their own notwithstanding these heary losses, then it follows that of the calves dropped each year (approximately 
$5,000)$, at least 48 per cent live to be 3 years old. If the herd just holds its own, the death loss each year would be about 1,200 , or onefourth of the calves; $\$ 00$, or one-fifth of the yearlings; 600 , or onefifth of the 2-year-olds; and 2,400 mature animals. Comparison of these figures with those of the losses by starvation of the calves during the past three seasons shows how rapidly the total number of elk must have diminished.

\section{FEEDING IN WINTER.}

The two winters preceding the past one (1910-11) had been unusually disastrous to the elk, and some feeding had been done. When it became evident, following the crusting of the deep snowfall of early January, that the loss was likely to be unprecedented, the legislature was appealed to and promptly made an emergency appropriation. As a result, about the 15th of February the feeding of hay was begun on as large a scale as possible. The construction of a large dam by the Reclamation Service at the outlet of Jackson Lake had created an abnormal demand for hay, and an amount approximately equal to the normal excess supply had already been taken out of the valley. It was, therefore, possible for the State to procure only about 250 tons, and, while this saved large numbers of the animals, it was far less than the amount needed. Arrangements were usually made to have the hay fed by the person of whom it was purchased, a certain amount, varying with the number of animals which could be most readily reached, being hauled each day to some point easily accessible to them. The elk soon learn the time of feeding and come readily to meet the loads. (See Plate V.) It is the custom of most of the feeders to drive past a band, and, as the more eager of the animals follow the load, the herd is gradually "strung out," in popular phrase; that is, becomes scattered in a long line. The course is then retraced or paralleled and the hay is thrown out in small quantities at short intervals. This method insures a fair share of hay to most of the animals, large and small. The latter part of the afternoon is considered the best time for feeding the elk, since they are then fortified for the night. One of the results of feeding is that the animals become extremely tame, especially when approached only in vehicles or on horseback. This familiarity, however, is quickly lost when the feeding is discontinued, and within a few weeks those which ate freely from the hand of their benefactors become as wild as ever. It is supposed by some that the feeding during past years has caused the animals to seek the region earlier, and it is a fact that their advent in the autumn of 1910 was sooner than usual, but probably this resulted from the weather conditions rather than from the fact that they had been fed during the previous winter. 


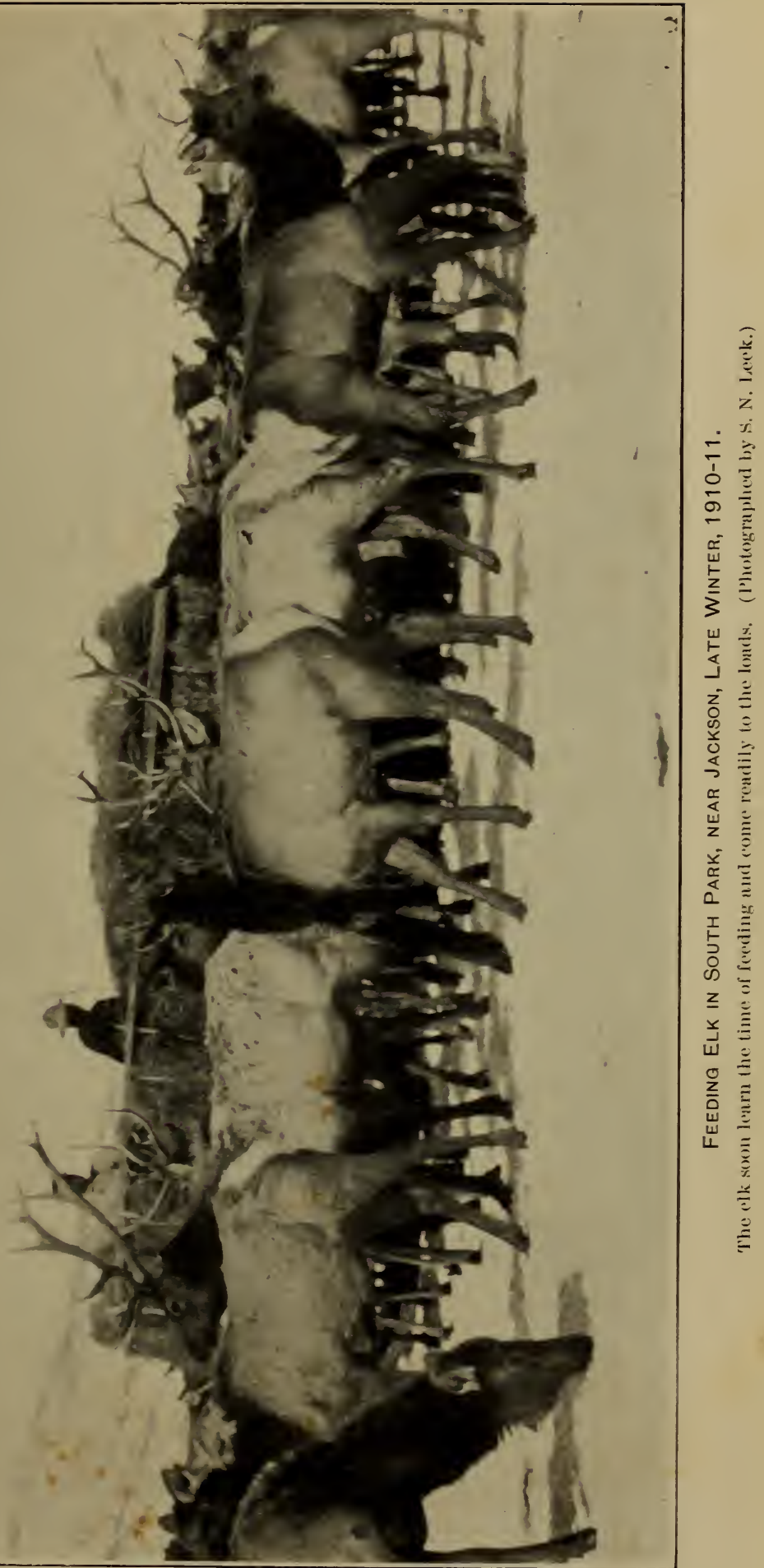





\section{IIFE HISTORY OF ELK.}

\section{DISTRIBUTION IN SCMMER.}

The elk which winter in the Jackson Hole region come from the Gros Ventre and other ranges to the eastward, and from the mountains lying between Buffalo Fork of Snake Rirer and Yellowstone Lake. It has been popularly supposed that most of the Jackson Hole elk summer in the Yellowstone National Park, but in reality about four-fifths of them breed and spend the summer entirely south of the park boundaries and therefore within the State of Wyoming. Of these probably the majority summer north of Buffalo Fork in the State game preserve, but large numbers remain in summer in the Gros Ventre Range and in the mountains about the tributaries of Gros Ventre River. A few calve and remain all summer among the foothills and buttes close to the ralley, even as low as 7,000 feet. Some summer along the east side of the Teton Range, but these are so few as to be negligible. To the south of Jackson Hole proper several hundred summer in the higher parts of Hoback Basin and descend into this ralley in winter, when their numbers are augmented by the orerflow from Jackson Hole.

\section{MOTEMENTS OF ELK IN AUTUMX.}

With the advance of the season in autumn the elk leare the higher altitudes where they hare spent the latter part of the summer and seek lower levels. They move southward gradually, and by the time the snow becomes deep most of them desert the mountains altogether and take up their residence in the ralleys. The high region north of Buffalo Fork comprising the State game preserve is then comparatively deserted by the animals, but south of that ralley a few scattered bands composed mainly of old bulls pass the winter at from 7,000 to 9,000 feet, usually on northerly slopes where the snow, not being exposed to the heat of the midday sun, does not crust, but remains soft enough to permit the animals to reach the grass by pawing. In moring southward from the game preserve the animals pursue more or less definite routes. Large numbers are in the habit of going along the eastern border of Jackson Lake to the vicinity of its outlet, where they cross the narrow arm of the lake or swim the rapid river below the outlet. Of these possibly the majority cross the plains to the lower part of Jackson Hole. Other large bands cross Buffalo Fork in various places and, ascending the tributaries of Black Rock and Spread Creeks, cross to the valley of the Gros Ventre, where they arrive in numbers in Norember. Some of these bands, usually the later ones, remain on Black Rock and Spread Creeks during the entire winter, and two or three thousand usually pass the winter in the valley of the 
Gros Ventre. The majority, however, move southeastwardly along the foothills to the lower part of Jackson Hole. In 1910 they came about the last of November. The open valley between the hills and Snake River, a part of which is known as Antelope F.lats, was formerly a favorite migration route for these animals, but increasing settlement has lately caused them to seek almost entirely the shelter of the fouthills to the eastward. Besides those which winter in the valley of the Gros Ventre within the mountains, a few hundred frequent the willow swamps of its lower stretches. A few winter about the upper Gros Ventre Butte (usually called the Black Tail Butte), and the low elerations, called the East and West Gros Ventre Buttes, which occupy a considerable area in the middle part of Jackson Hole, harbor a number of good-sized herds. The favorite haunt of the animals, however, is the large marsh bordering Little Gros Ventre or Flat Creck above the town of Jackson. This occupies an area about 5 miles in length and varying in width from 1 to 2 miles. Flat Creek, which traverses it, is partially dammed near the town of Jackson by a ledge of rock, and the slackened current, permitting the deposition of great quantities of silt, has caused the formation of this marsh. A rank growth of coarse grass covers the greater part of this area, much of which is so wet during ordinary seasons as to prevent harvesting. Sereral large warm springs drain into it, and these cause parts of the stream to remain open during most or all of the winter, but the marsh itself is partially flooded and freezes early, allowing the animals to gain access to such forage as remains above the ice and snow. During the past winter an unusually heary fall of snow in early January was heavily crusted as the result of a wet storm and the animals were prevented from obtaining more than a small proportion of the rich store of food which should have awaited them. The surrounding hillsides, as a result of the unusually dry summer of 1910 and the consequent excessive grazing, did not afford the usual amount of food, and before the winter was half over the condition of the herds had become appalling.

DEPREDATIONS BY ELK IN WINTER.

The passage of bands of large animals through even a sparsely settled country naturally results in some damage to fences. The ordinary rail fence used for the confinement of stock offers no serious impediment to the elk, especially when snow lies deep on the ground and eddies of air about the corners of fences and in the lee of knolls form deep drifts. Thus fences which cross the routes frequented by these animals are usually broken down early in the winter. The most serious damage, however, results from the efforts of animals to reach haystacks, and in this respect the settlers find it almost impossible to protect themselves. Besides their ability to leap or scramble over high fences, the elk show great dexterity in clambering sideways between the poles and, if even a narrow space is left, they frequently 
force apart even strongly fastened rails. The difficulty is, of course, increased by the tendency of drifts to form about high objects like haystacks. High fences of woren wire would doubtless prove much more effectire than the rail fences in common use, but the initial cost of this fencing and the difficulties of transportation have prevented its adoption. Many settlers, despairing of fencing the starving animals from the hay needed for their stock, are forced to sleep beside the stacks during much of the winter, a task which is not conducive to a tolerant riew of the situation.

\section{HABITS IN WINTER.}

The life of the elk during a winter so serere as that of $1910-11$ is a constant struggle to preserre existence. Following the path of least resistance, the majority of the animals, including most of the young. calves, find themselves in the raller, where they are soon driren to browse on the willows and other shrubs already nearly destroyed during previous winters. The elk soon eat the smaller twigs and then are forced by hunger to attack the bark and larger branches. The woody fiber thus swallowed has little nutriment and is without doubt actually injurious, especially to the rounger animals. Eren sagebrush is drawn on for sustenance. Haystacks about ranches are, of course, eagerly sought. If insecurely fenced, they are soon at the mercy of the starving animals, which frequently die from orerfeeding. When they find the stacks securely fenced, large numbers die immediately around them. The larger animals by standing on their hind legs mar be able to reach a few morsels of hay, while the young calres in the group are trampled by their larger associates and perish miserably.

Many herds, composed mainly of adults of both sexes, sometimes accompanied by a few calres, remain on the open hillsides and among the aspen and spruce woods of the mountain slopes. Although there is usually some mortality among these herds, they fare better on the arerage than those which seek the ralleys, since they are in smaller bands and have a larger proportion of older and experienced animals. Besides securing some withered grass, they browse on the twigs and bark of the aspen poplar and to a less extent on the spruces. Any brush left by woodchoppers is eaten at night, as the animals are freely nocturnal. Some of these bands make forays to the rallers at feeding time or during the night and return to the hills to rest.

\section{WINTER MORTALITY OF ELK.}

Apart from the death of elk from actual starration, there is, of course, the normal mortality, most of which takes place in winter, when the conditions surrounding the animals are hardest. Eren in 
mila winters and in times of plentiful food supply, many of the older animals of both sexes die. Owing to the fact that a large proportion of the animals killed for food during the autumn months are females, a great many young calves are left motherless and are in a more or less weakened condition when winter comes on. Furthermore, many of the late-born calves are poorly equipped to withstand the winter, and this is likely to be true also of many of the cows which have borne and nursed young the previous season.

A conservative estimate places the number of elk which died of starvation in the Jackson INole region during the winter of 191011 at some 2,000 to 2,500. Of these, by far the greater number were calves of the previous year. Probably 75 per cent of the calves which came into the valley in November and December had perished of starvation before the end of the following March. In some bands the loss of calves was as high as 90 per cent, but other bands suffered less. The greater part of the loss occurred before feeding began, but large numbers, both calves and older animals, were so weak that they died even when receiving what would ordinarily have been an abundance of food. Many, in fact, on being fed after a period of starvation, die almost immediately. There is eviclently little difference in the relative mortality of the sexes in adult elk, and out of 75 calves examined for sex 32 were males and 4.3 were females, indicating that in the case of the young the burden on the sexes is not strikingly unequal.

\section{HABITS IN SPRING AND EARIY SUMMER.}

As spring advances and the sides of hills bordering the valley become bare, the elk, especially the older animals, leave their haunts in the lower part of the valley and seek the hillsides, where they subsist on the dry grass which has been exposed by the melting of the snow. At the time of my arrival, about the middle of March, they had already begun to work back into the hills, and the numbers being fed were much less than originally. Many of the animals at this season spend a part of their time on the hillsides, visiting the feeding grounds at the time when they have been accustomed to be fed. As the spring advances, this movement into the hills becomes more and more pronounced, until the valley is entirely deserted. The last ones left that part of Jackson Hole south of the Gros Ventre Buttes, known locally as South Park, about April 26, some time after feeling of hay had been discontinued. They were subsisting on the green grass then springing up on the borders of some.spring-fed creeks. They were seen on the adjacent hillsides until early May. In the swamp north of Jackson a large herd remained later. Investigation showed that they were feeding on the green leaves of the 
coarse marsh grass, evidently the plants which had grown in autumn after hay harvest. This grass had been kept green and succulent by its covering of ice and snow. In early May the icy flooring which had remained solid beneath the tangled grassy covering no longer held up the animals, and they all left about May 10. For some time longer upward of 100 remained on the East Gros Ventre Butte, several hundred feet higher than the valley level. Here they lived on the grasses and herbaceous plants which were fast springing up. These elk remained here until about May 25, and then part or all of them crossed westward and joined others on the larger West Gros Ventre Butte, which afforded them more protection. Upward of 100 were seen there as late as May 31, and a few remained all summer.

Some of the older bulls dropped their antlers about March 25, but the shedding continued for several weeks. Among a herd seen May 4 were a number of bulls still bearing horns, but by May 15 even the younger bulls had all dropped them. As the shedding of antlers is dependent on the general condition of the animal, the process was delayed by the severe winter and late spring. In an earlier spring following a normal winter the new horns are already well grown in May, but in 1911 that month found most of the bulls with their horns scarcely started, and in mid-August many were still in the velvet.

BIRTII OF YOUNG.

About 75 per cent of elk cows over 2 years old bear young. The majority of calves are born between the 25 th of May and the middle of June. Nearly all the testimony obtained on the subject is to the effect that only one calf is born at a time. A few thought that twins sometimes occur, but it seems probable that this opinion arose from the fact that a cow elk is frequently followed by two calves during the summer, the extra one being the deserted or orphaned offspring of another cow. Many of the hunters had examined large numbers of female elk with calf, and none of these ever found more than one fetus. The proportion of the sexes at birth is nearly even. Large numbers of the cows have their young in the hills in the ricinity of Jackson Hole, but probably the majority of the animals which come from north of Buffalo Fork return there before dropping their young. This varies according to the season, an early spring allowing a greater proportion to move northward before calving. The young are usually born in a thicket, very often among aspens, and are carefully concealed by the mothers when they have occasion to leave them. The calves are said to begin to graze at the age of 4 to 6 weeks, and many are weaned in September. In some cases, however, weaning does not occur until October, November, or even later. 



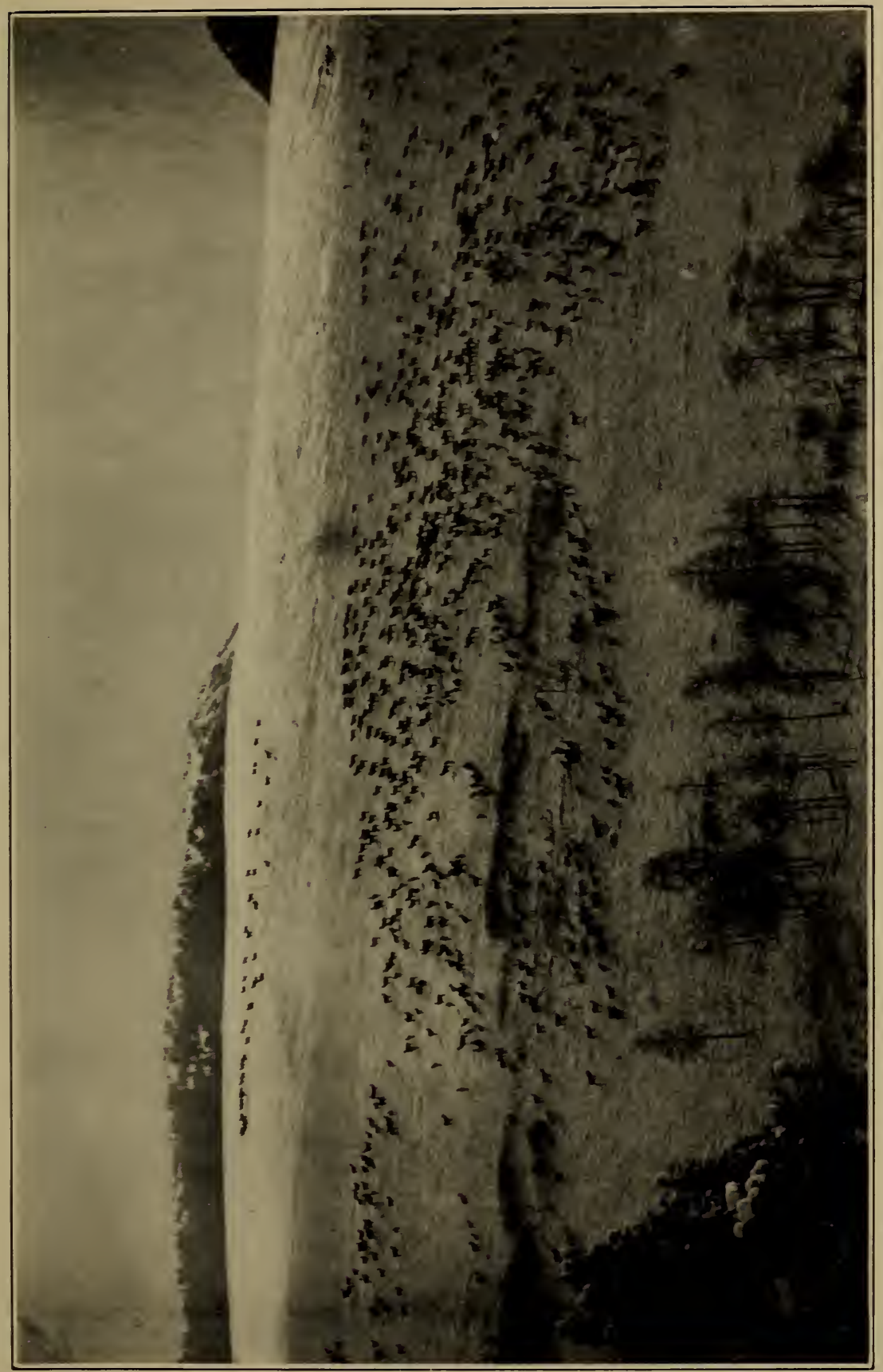



become unwilling hosts of large numbers. It is doubtful if the elk are killed by ticks, but in the spring they are undoubtedly weakened by the pests.

\section{ILIEGAL KILLING OF ELK.}

The great majority of the people of Jackson Hole are opposed to the killing of elk contrary to law, but there is more or less illegal killing throughout the year. Some of the lawbreakers became residents of the region because of the opportunity afforded for making a living in whole orin part from game, and many of these regard the elk as their natural prey at any season. Many also are "old-timers"-men whose experience in the West antedates restrictive laws and the period when they became necessary. Others justify themselves in illegal killing "because so many of the elk die of starvation." It is hoped that the conditions which furnish this excuse may be abolished.

Lowest in the scale of all the enemies of the elk is the tusk hunterthe creature who, on the chance of gaining a dollar or two, kills one of the largest and finest of our game animals and, taking only the tusks, leaves the body to go to waste. The wolf kills that he may live, but the tusk-hunter slays only that he may escape honest labor. Under cover of the mail he forwards his booty undetected to dealers who dispose of the tusks to purchasers who seek only trophies, indifferent to how they are obtained.

The warden service in the Jackson Hole region at the present time is very inadequate. The game preserve, with an area of not less than 1,000 square miles, is little patrolled except by the Federal forest rangers, whose regular duties will not permit much attention to game interests. In addition to this there remains an area comprising at least 1,500 square miles, and this great tract of rough country is under the care of one deputy game warden with one or two assistants.

\section{TRANSPORTATION OF ELK.}

The plans of the Biological Survey contemplated the removal of a number of elk to other States, where they could be liberated on suitably protected ranges and form the nucleus of new herds.

The problem of transportation is a difficult one, because the Teton Range, 2,000 feet higher than the valley of Snake River, must be crossed on the way to the railroad. Spring, moreover, when the snow is disappearing on both sides of the range and is softening and settling on the Teton Pass, is the most unfavorable time of the year for moving live animals. The facilities for transportation were not extensive, and the number captured, therefore, was necessarily limited by the accommodations at our disposal. A dozen of the more vigorous animals of various ages were selected from a herd being fed in the southern part of Jackson Hole, and on April 12 we started with them for the railroad. Hay or alfalfa was provided for them morning and night and water at least three times daily. They readily 
look both food and water and were given as much of both as they wanted.

A delay of a few days would have necessitated making the first lap of the journey on wheels, then changing to sleds, and again to wheels. Fortunately, bowever, enough snow remained in the valley to allow the use of rumers, and but one change was necessary. Racks covcring the entire wagon bed were constructed, and from three to five elk were placed in each load. A decided lowering of temperature, accompanied by a snowstorm, made traveling over the Teton Pass unpleasant and arduous, but was of distinct assistance in the successful accomplishment of a task always dreaded at this season. In our case the normal difficulties were magnified by the nature of our loads, which, though not of excessive weight, were bulky and topheary. Similar attempts in the past have almost invariably been attended with some loss; but by constant vigilance and the hearty cooperation of our assistants the mountains were crossed without mishap. Near Victor, Idaho, close to the western base of the range, bare ground was reached, and our loads were changed from runners to wheels. This was done by lifting the wagon bed and racks by means of a derrick, without removing the animals. The roads from this point were in excellent condition, and the completion of the trip was merely a matter of time.

Upon our arrival at St. Anthony, arrangements were made at once for shipping the animals. The National Bison Range at Ravalli, Mont., and the Wichita Game Preserve in Oklahoma had been selected as the places to be supplied, and the lot was divided between them. It is gratifying to report that the animals in both shipments reached their destinations in excellent condition and that the project of reestablishing the species in these depleted localities has been successfully inaugurated.

\section{WINTER REFUGE FOR ELK.}

The establishment of a winter refuge, where the feed can be preserved by excluding stock during the summer, is essential for the proper protection of the elk. Such a refuge should be of considerable size, should be situated in a valley which the elk naturally seek, and should comprise pasture lands, as well as meadows which will produce hay for feeding the animals after they have exhausted the available forage. An ideal situation would includo also a tract of somewhat elevated land, to which the animals could retire for rest.

In 1906, when increasing settlement and the attendant grazing of the mountain parks began to affect the welfare of the wintering herds of elk, Mr. D. C. Nowlin, then Stato game warden, suggested the setting aside of an area including a large part of the valley of the Gros Ventre River for the exclusive use of the elk and other game. Luter, in his annual report for 1908, he outlined the proposed area, 
which was embraced by the Teton National Forest, and included several claims occupied by stock ranchers, and recommended its acquisition by the State.

Early in 1909 a joint memorial was presented to Congress by the Wyoming Legislature requesting that a tract comprising six townships of public land in the Gros Ventre region be granted to the State for a winter game refuge, and that provision be made also to acquire the holdings of the few settlers thereon located, who favored the proposition and were willing to dispose of their land at a fair price. Owing mainly to the opposition of the people of Jackson Hole, no result was obtained.

In the course of the present investigation an attempt was made to ascertain the sentiment of the people of Jackson Hole regarding winter refuges. About 40 residents of the valley, most of them living within a few miles of the town of Jackson, were asked specifically whether or not they favored the acquisition of a tract for a winter refuge. Of this number, 27 favored the securing of a tract in the settled part of the valley. Most of the remainder were in favor of feeding hay in winter, while a few believed that some area should be set aside for the elk but were indifferent as to its location. The few inhabitants of the Gros Ventre Valley were, generally speaking, in favor of the establishment there of a reserve, and several from other sections were likeminded. It is evident that, while the inhabitants of the region as a whole have heretofore violently opposed the setting aside of an elk refuge on the Gros Ventre, they are really in favor of a refuge and differ mainly as to its location, the people in the valley advocating its establishment there, while the settlers on the Gros Ventre favor that section as its site.

The Biological Survey looks on the establishment of one or more winter refuges as the best solution of the problem of properly caring for the elk in winter. An area in the lower part of the region is of prime importance, since there the greatest number of elk resort and there an area of a given size can be made to support the greatest number of animals. On the other hand, the establishment of a second refuge in the Gros Ventre Valley would be comparatively inexpensive and would gradually be the means of detaining there in autumn a considerable number of the elk which would otherwise keep on to the lower country. It has been estimated that 600 tons of hay can be harvested on the claims now occupied on the Upper Gros Ventre, and this amount, with the available forage, would support more elk than now winter there. The number which might be supported on a properly managed refuge in the Jackson region would be limited only by the size of the reservation. It is earnestly recommended that at least one winter refuge for elk be established. 
